\title{
The Perception and Usage of Google Drive Among Higher Education Institution Students in Brunei Darussalam
}

\author{
Nur Diyana Rossiman, Universiti Brunei Darussalam, Brunei \\ Norzaidah Hidayah Rashid, Universiti Brunei Darussalam, Brunei \\ Wardah Annadiah Ahmad Ramzuna, Universiti Brunei Darussalam, Brunei \\ Mohammad Nabil Almunawar, Universiti Brunei Darussalam, Brunei \\ iD https://orcid.org/0000-0001-5296-2576
}

\begin{abstract}
Recently cloud computing services have been adopted by many people and organizations. Google Drive is one of the cloud computing platforms that has gained popularity among students in higher education institutions. This study examines the perceptions and the current usage of Google Drive among students in higher education institutions in Brunei Darussalam. The study adopted the technology acceptance model (TAM) and two additional factors, namely perceived speed of access (PSA) and perceived security (PS). The primary objectives of this research are to explore the factors affecting the usage of Google Drive by the students in higher education institutions in Brunei, to investigate the perceptions of the students on the use of Google Drive, and to find whether attitude influences the behavioral intention to use Google Drive among the students. The findings of this study connote that the students' perceptions on Google Drive have a significant influence towards their attitude to use Google Drive which in turn influence their behavioral intention to use Google Drive in the future.
\end{abstract}

\section{KEYWORDS}

Brunei Darussalam, Cloud Computing, Cloud-Based Storage, Google Drive, Technology Acceptance Model (TAM)

\section{INTRODUCTION}

Cloud-based storage has been widely adopted by many individuals as it provides many advantages over local storage, such as ubiquitous access with multiple devices through the Internet which can be shared with sufficient access control. In general, cloud computing provides users with computing resources that enable them to connect and share these resources conveniently. Besides individuals, cloud computing such as cloud-based storage has been adopted by organizations including educational institutions particularly it was used extensively by undergraduate and postgraduate students (Mary and Rose, 2020). Hence, cloud computing is seen to greatly affect both teaching and the education environment (Ercan, 2010). According to Ashtari \& Eydgahi (2017), there is a noticeable growth 
in the use of cloud-based applications in higher education institutions. In addition, Mary and Rose (2020) have revealed in their research paper the top frequently used cloud data storage and Backup Applications by students are Gmail (58.5\%), Google Drive (36.11\%) and Google Calendar (25\%).

One of the most popular cloud-based storage is Google Drive. Many students nowadays use Google Drive as a tool to enhance their academic experience. In addition, Google also provides many free useful applications that can increase the utilization of Google Drive. Students and educational institutions see this as a great educational technology (Sclater, 2009). However, there is still limited research on how far cloud-based storage such as Google Drive is accepted and used by students in higher education institutions.

A considerable amount of studies and attempts had been made in the past to justify and forecast the acceptance of information system technology among users (Venkatesh \& Davis, 2000). Consequently, this has led to the development of several theoretical perspectives translated in the form of theoretical models to rationalize an individual's behavior on information system technology acceptance. In order to understand the student perception and usage of Google Drive, Technology Acceptance Model (TAM) is adapted as the theoretical foundation in this research.

Additionally, there is a lack of extensive research being done on the perception and usage of Google Drive among students, particularly in higher education institutions. To fill the gap, this paper will look into the current usage of Google Drive among students of higher education institutions in Brunei. The primary objectives of this research are; i.) to explore the factors affecting the usage of Google Drive by the students in higher education institutions of Brunei, ii.) to investigate the perceptions of the students on the use of Google Drive and iii.) to find whether attitude influences the intention of using Google Drive among students.

This research also aims to provide references for future researchers who may intend to further explore the usage of cloud storage such as Google Drive in any area or field that they deem relevant. Therefore, it is hoped that this paper will contribute in the following ways:

- A beneficial study in aiding the higher education institutions particularly in Brunei Darussalam to be more accepting and understanding of the convenience as well as efficiency of using Google Drive.

- The infrastructure of cloud storage service should complement the Technology Acceptance Model (TAM) in order to ensure that it is favourable for Google Drive to be convenient for use as it would encourage users to opt for its service.

- The speed of access and security are useful tools as consideration in assessing the determinants of attitude particularly in the context of Technology Acceptance Model (TAM).

- Can help better understand the Bruneian higher education students' preferences in utilizing cloud storage service.

- Recommendation on the initiatives will also be provided and this can be a future reference.

The rest of the paper is organized as follows. In the next section, we present the literature review on the relationship between the variables used in this research. Followed by the research framework and hypotheses in section 3 and the research methodology in section 4 . The data analysis and results are reported in section 5 and the discussion is presented in section 6 . The last two sections are the conclusion and limitations as well as future studies.

\section{LITERATURE REVIEW}

\subsection{Google Cloud Storage Service}

Since the commercialization of the Internet, many innovators took the opportunity to create online business platforms and the founders of Google, Sergey and Page, jump into the bandwagon into 
building the technology phenomenon (Greenstein, 2000; Vise, 2007) and it was in 1998 Google Inc. was officially born. In addition to that, Google has restructured its company into Alphabet Inc. in 2015, consequently becoming the parent company of Google (Page and Pichai, 2015). Alphabet Inc. is made up of a collection of companies with Google as its largest company where Google web search has remained the top and most used web search engine globally (Page and Pichai, 2015). Since then, Google continues to evolve and create several amounts of Google services or 'applications' used by people globally and often provides a free service to remain competitive in the market (Google, n.d.).

Subsequently, there are ample free web-based applications where the user does not have to install the software yet can access them via the Internet. Google launched its Google Drive in 2012 which allowed users of cloud storage services to store and access files such as pictures, documents, PDFs, designs, drawings, recordings, videos, and more in any place where internet is accessible by the user with free 15GB storage (Barbee \& Prindle, 2018; Kovach, 2012). The user can access and work on their files while offline provided the user installed the offline Chrome extension (Barbee \& Prindle, 2018). Furthermore, other Google services such as Gmail, Google Docs, Chrome, YouTube as well as Google Android operating system are incorporated in Google Drive (Rouse, 2012).

It is worth noting that Google Drive does not only provide a cloud storage service but also incorporates a number of collaborative tools where other users can be given invitations to collaborate allowing multiple users to view and edit simultaneously and in real-time on a project over the web (Google, n.d.). According to Google (n.d.), the security of the files uploaded into Google Drive is encrypted using SSL, ensuring that all Google services are protected and safe while still being easily accessible in the user's smartphone, tablet or computer. Google Drive's main competitors are Microsoft OneDrive, Dropbox and Apple iCloud.

A study by Shana and Abulibdeh (2017) revealed that Google Docs within Google Drive was widely used by students because it can share files seamlessly as well as editing the documents directly in the cloud storage and for this reason students perceptions on ease of use of the said technology will affect their future attitudes and behaviours towards adopting cloud-storage services. However, the research only focuses on one university thus limits the result and therefore, it cannot represent higher education in UAE. Additionally, although the paper used Technology Acceptance Model (TAM), variables such as security need to be examined further.

Moreover, previous study on the acceptance and intention to use Google Drive among higher education students by Chandra and Hartono (2018), where they used the Technology Acceptance Model (TAM) as the theoretical base of their study discovered that there was a significant link between the two variables, namely perceived ease of use and perceived usefulness. In addition this study also discovered that the attitude of the students towards using Google Drive influenced their intention to use it. As a result, this study concluded that the variable perceived usefulness was a dominant factor that greatly influenced the attitude of students towards using Google Drive which then led them to have the intention to use it. This study was conducted using a quantitative method by distributing an online questionnaire via google form in the period of 5 months to all higher education students in Indonesia. Data obtained from the questionnaire was then analysed using Microsoft Excel and SmartPLS application.

\subsection{Technological Acceptance Model (TAM)}

Researchers have extensively applied the Technology Acceptance Model (TAM) in the field of technological research ever since it was proposed in 1986 by Davis (1989). The theoretical basis of the Technology Acceptance Model (TAM) model was developed from the theory of reasoned action (TRA) which centered around two assumptions that the acceptance and behavioral motives of a user towards information system technology are determined by his perceived ease of use (PEU) and perceived usefulness (PU) (Lederer et al., 2000; Lee et al., 2003; Ayeh et al., 2013). The study adopted the Technology Acceptance Model (TAM) model as its theoretical framework and formulation of hypothesis however, the model has also added two variables, namely, perceived speed of access 
(PSA) and perceived security (PS) of which is believed to be the determinants to the adoption of cloud computing namely the cloud-based storage (Changchit and Chuchuen, 2016).

\subsubsection{Perceived Usefulness (PU)}

The definition of perceived usefulness (PU) as given by Davis (1989) is the degree to which a user's belief of an information system technology would enhance work. Thus, in this research, perceived usefulness (PU) means the degree to which the student believes that using Google Drive would further improve his/her work.

\subsubsection{Perceived Ease of Use (PEU)}

Davis (1989) stated in his study that perceived ease of use (PEU) is defined as the degree to which a user's belief of using an information system technology would be effortless. Hence in the context of this study, perceived ease of use (PEU) is referred to as the degree to which the student believes that using Google Drive would be simple and easy.

\subsubsection{Perceived Speed of Access (PSA)}

Access speed is an important parameter for users to accept any cloud storage services. Changchit and Chuchuen (2016) defined the perceived speed of access as the degree of a person's belief that accessing data on cloud storage service would be at an equivalent pace as when the data is stored locally in their personal computers. Users do not have any speed problem to access their files from the harddisks of their computers. They expect an acceptable speed to access their files from cloud storage service. Hence, the study will focus on students' perception towards the speed of access of data on Google Drive at a reasonable speed over the Internet, which may also be one of the factors that may affect the attitude towards using Google Drive.

\subsubsection{Perceived Security (PS)}

Perceived security is the degree of a person's belief that their data in cloud storage service will not be viewed or breached by unauthorized parties and is protected against loss, danger as well as criminal activity (Flavián \& Guinalíu, 2008; Changchit, 2008; Khansa \& Zobel, 2014). Therefore, in this study, the students perceived security would be a key factor in determining the usage of Google Drive.

\subsubsection{Attitude Towards Using Google Drive (A)}

Attitude refers to a person's response to prior catalysts whereby it can be a favorable or adverse response to external stimulus or environment (McGuire, 1969; Fishbein \& Ajzen 1975). Previous Management Information System (MIS) researchers emphasized that understanding the antecedents of attitudes is crucial (Robey, 1979; Swanson, 1982; Lee, 1986; Igbaria \& Chakrabarti, 1990; Igbaria, 1990; Thompson et al., 1991; DeLone \& McLean 1992; Torkzadeh \& Dwyer, 1994; Etzadi-Amoli \& Farhoomand, 1996; Szajna, 1996; as cited by Al-Gahtani \& King, 1999). Thus, this study examines the factors influencing the students' attitude towards using the Google Drive.

\subsubsection{Behavior Intention to Use Google Drive (BI)}

There are various definitions and interpretations of behavioral intention used across academic research. However, all of them share the same concept of behavioral intention where it predicts an individual's probability to connect with certain behavior (Venkatesh et al., 2003; Thompson et al., 2006; as cited by Wang \& Liu, 2009). Thus, behavioral intention is the extent to which there is a willingness and motivation in performing a particular behavior (Fishbein \& Ajzen, 1975; Ajzen \& Fishbein, 1980; Warshaw \& Davis, 1985; Ajzen, 1991). In this study, behavioral intention is referred to as the student's conscious or deliberate intention to use Google Drive. 


\section{FRAMEWORK AND HYPOTHESES}

\subsection{Theoretical Framework}

Nowadays, the use of cloud storage services have been prevalent as they allow users to store, share and access digital contents remotely via the Internet with a compatible device (Sadik, 2016). One of the most prominent cloud storage platforms is Google Drive. Therefore, in the context of this study, Google Drive acts as the information system technology that is being investigated through the perceptions of the students based on the Technology Acceptance Model (TAM). The theoretical framework of this study has been developed with the adaptation of the Technology Acceptance Model (TAM) as its theoretical model. This theoretical model had been extensively used and established by researchers in the field of technology. However, we have extended the Technology Acceptance Model (TAM) in developing our theoretical framework by including two more independent variables: Perceived Speed of Access (PSA) and Perceived Security (PS). We think these two additional variables are important to include as Google Drive is accessed through the Internet. Altogether, there are four independent variables, namely, Perceived Usefulness (PU), Perceived Ease of Use (PEU), Perceived Speed of Access (PSA) and Perceived Security (PS), where as the intermediary variable is Attitude towards using Google Drive (A), and one dependent variable which is Behavioural Intention to use Google Drive (BI). As a result, a relationship of these variables are developed which are then illustrated in figure 1 below. Hence, in this research, the Technology Acceptance Model (TAM) is adapted to investigate the students' perceptions on Google Drive and how their attitudes towards it influenced their behaviour in using Google Drive. Figure 1 below shows the theoretical framework.

Figure 1. Theoretical Framework

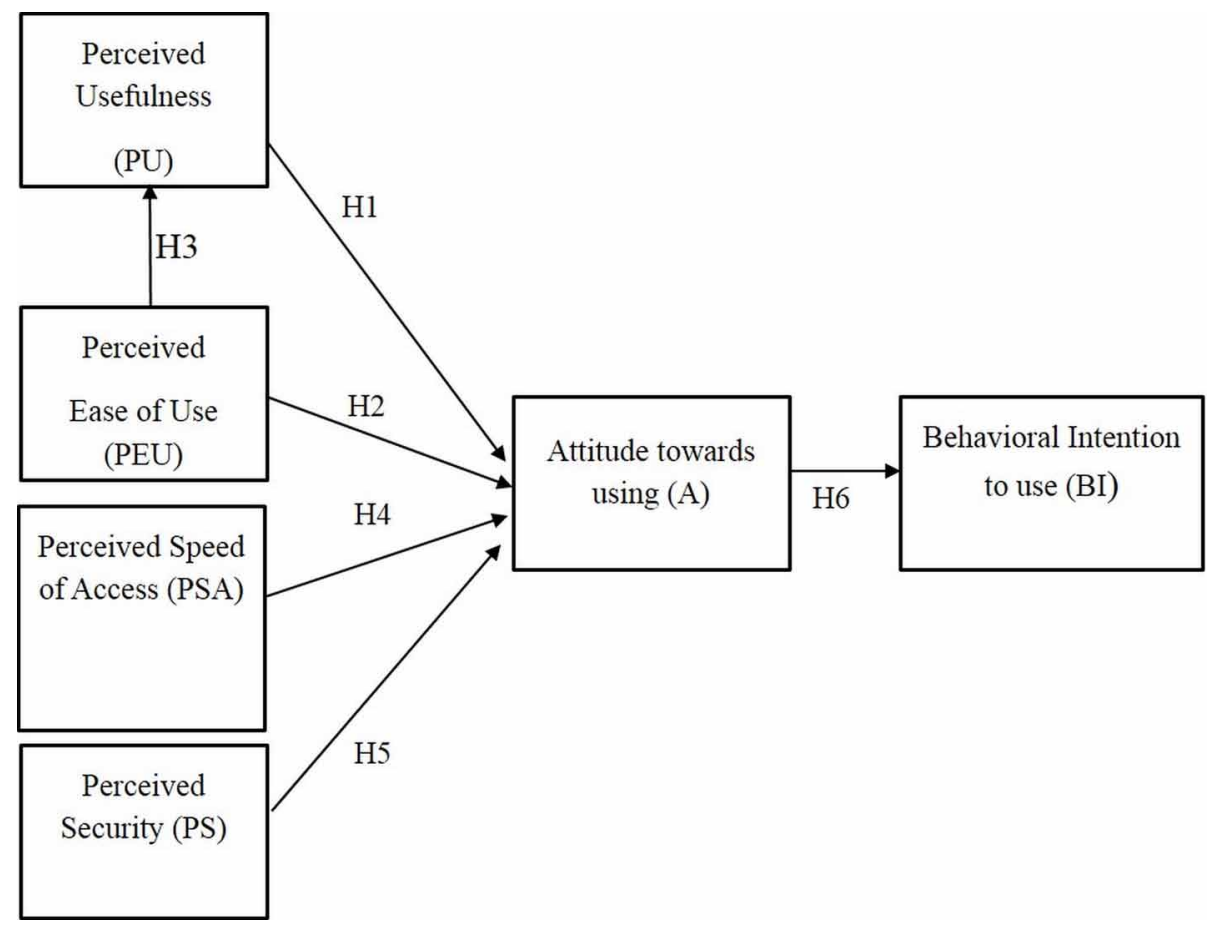




\subsection{Hypotheses}

Correspondingly, based on the theoretical framework from figure 1 above, a total of six hypotheses were established in this study. The six hypotheses were derived from the relationships established in the theoretical framework above that is adapted from the Technology Acceptance Model (TAM). The attitude of a user towards using Google Drive is believed to be influenced by two dominant factors namely, perceived usefulness and perceived ease of use (Abubakar, 2019). In addition, it is believed that perceived ease of use has a direct influence on perceived usefulness (Abubakar, 2019). We also believed that perceived speed of access and perceived security has an influence towards a user's attitude in using Google Drive. Lastly, it is believed that the attitude of a user has a direct influence on the behavioural intention of the user to use Google Drive (Abubakar, 2019). Hence, the following are the proposed hypotheses of this research study based on the aforementioned variables in the theoretical framework.

H1: Perceived usefulness (PU) will positively influence attitude towards using Google Drive among the students.

H2: Perceived ease of use (PEU) will positively influence attitude towards using Google Drive among the students.

H3: Perceived ease of use (PEU) will positively influence perceived usefulness (PU) towards using Google Drive among the students.

H4: Perceived speed of access (PSA) will positively influence attitude towards using Google Drive among the students.

H5: Perceived security (PS) will positively influence attitude towards using Google Drive among the students.

H6: Attitude will positively influence the students' behavioral intention to use Google Drive.

\section{METHODOLOGY}

\subsection{The Methods of Collecting Data}

The data for this study were mostly collected using a quantitative method by developing electronic questionnaires developed using Google Form. In addition, the use of non-probability method of convenience and snowball sampling was applied as sampling methods which speed up data collection and allow easy accessibility by spreading the electronic questionnaires online (Evans \& Marthur, 2005). The link to the electronic questionnaires was shared via social media such as Whatsapp and Facebook to target respondents. The survey sample can be referred to the end of this paper (see Appendix).

\subsection{Research Overview}

The research focused on the students from higher institutions in Brunei namely Universiti Brunei Darussalam (UBD), Universiti Teknologi Brunei (UTB), Sultan Sharif Ali Islamic University (UNISSA), Seri Begawan Religious Teachers University College (KUPUSB), Politeknik Brunei, Institute of Brunei Technical Education (IBTE), International Graduate Studies College, Laksamana College of Business, Kemuda Institute and Micronet International College. An online survey was created for the students' ease of use taking into the consideration of the time and cost constraints. The collection of data from the students helped to gain information on the usage and capture students' perception of Google Drive. Subsequently, data obtained from the questionnaires were presented as results in the Findings section of this paper, along with a thorough analysis to describe the factors that affect the usage as well as the perception of Google Drive which then contribute to the write up of the discussion and eventually conclude the study. 
Online questionnaires were in the form of Multiple-Choice Questions to illustrate statistical data and percentages. Furthermore, 5-point Likert scale questions were used to quantify the variables, with 1 being "Strongly Disagree" or "Very Unlikely" and 5 being "Strongly Agree" or "Very Likely".

\subsection{Sample of Questions}

The study targeted a total of 250 higher education institution students in Brunei Darussalam. The structure of the questions were constantly evaluated in relation to understandings from the literature review which are mainly focused on the research statement of problems as well as the objectives.

The details of the questions can be referred to in the Appendix of which the questionnaires consist of three sections showed as follows:

1. Section A consists of questions related to the demographic profile of respondents such as gender, age and their level of studies (unibridge, undergraduate or postgraduate).

2. In Section B, the questions are associated with the respondents of IT literacy and their purpose of using Google Drive.

3. Questions relating to the six variables were included in Section C.

\subsection{Data Analysis}

There were 243 responses recorded from the online questionnaires via Google form in total. However, there were only 215 valid responses selected for data analysis as we only chose respondents who have used Google Drive. Hence, this resulted in a response rate of $88.5 \%$. Among the 215 valid responses, 130 were students from Universiti Brunei Darussalam(UBD), 28 responses were students from Universiti Teknologi Brunei (UTB), there were 11 respondents from both Universiti Islam Sultan Sharif Ali (UNISSA) and Institute of Brunei Technical Education (IBTE). Additionally, 14 responses were obtained from Politeknik Brunei, 10 respondents were from Seri Begawan Religious Teachers University College (KUPUSB), there were also 7 respondents from Laksamana College of Business, another 2 responses were also obtained from International Graduate Studies College and lastly there were 1 respondents each from Kemuda Institute and Micronet International College. The data obtained from the online questionnaire were then analyzed by using software applications, namely, Statistical Package for Social Science (SPSS) Statistics version 23.0 and Microsoft Excel.

\section{RESULTS}

\subsection{Data Cleaning and Factor Analysis}

Prior to analyzing the data, the collected data were first tested for any missing values and the outcome of the test showed that no missing values were discovered. This is then followed by conducting factor analysis of the data which was performed to know if this study has an adequate number of samples or not by using the Kaiser-Meyer Olkin and Bartlett's test. The outcome of the test is that the value of sampling adequacy is 0.813 which is more than the recommended value that is 0.6 (Kaiser, 1974). Therefore, this study indicated that its sampling was adequate. In addition, the Bartlett's test of sphericity showed significant result of $X^{2}(15)=655.587, p<0.001$ which means that the factor analysis is applicable to all 23 measure items (refer to Table 2).

\subsection{Descriptive Analysis}

The results from the descriptive analysis of the demographic data of the respondents (refer to table 3) showed that $76.7 \%$ of the respondents were female and $23.3 \%$ were male. Additionally, most of the respondents were aged between 18 to 24 years old which accounts for $74.9 \%$ of the total respondents. Meanwhile, respondents aged between 25 to 39 years old were found to be $16 \%$ of the total respondents and $1.4 \%$ were in the age category of 17 years old and below. $0.5 \%$ of the respondents 
were aged between 40 to 60 years old. In terms of the general IT skills of the respondents, $60.9 \%$ of the respondents considered themselves as having intermediate general IT skills, whereas $21.4 \%$ of the respondents considered themselves as novice in their general IT skills and the remaining $17.7 \%$ of the respondents considered themselves as savvy in their general IT skills.

Besides that, we also asked respondents whether they know about cloud computing, and from the data analysis it is revealed that $46.5 \%$ of the total respondents have heard about cloud computing while the remaining $53.5 \%$ have not heard of cloud computing. Subsequently, we also asked the respondents' frequency on using Google drive; $32.6 \%$ of the respondents use Google Drive 1 to 7 times $24.2 \%$ of them 1 to 3 times in a month, $20.5 \%$ more than once a day and the remaining $16.3 \%$ and $6.5 \%$ of the respondents use Google Drive less than once a month and were rarely using Google Drive respectively. Moreover, we also found out the respondents' reasons for using Google Drive in a descending order, where the majority of the respondents used Google Drive for online collaboration, followed by storage service, file sharing and lastly for assignment submission.

\subsection{Reliability Analysis}

The reliability of the measure items were tested using the reliability analysis in Statistical Package for Social Science (SPSS) to obtain the value of Cronbach's alpha for each of the variables. The result of the reliability analysis revealed that all the variables have the Cronbach's alpha values within the range of 0.7 to 0.9 as seen in Table 2. Cronbach's alpha values of 0.5 to 0.7 are regarded as moderately reliable and values that are more than 0.7 are regarded as highly reliable (Hinton et al., 2004). This indicates that all the measure items used are regarded as reliable.

\subsection{Correlation Analysis}

Table 3 displays the outcome of the correlation analysis that includes the mean of the variables, standard deviation and the respective Pearson's Correlations of the variables. In order to test all the proposed hypothetical relationships between respective variables (PU, PEU, PSA, PS, A and BI), the

Table 1. Demographic information of respondents

\begin{tabular}{|l|l|l|l|}
\hline \multicolumn{2}{|c|}{ Demographics } & \multicolumn{1}{c|}{$n=\mathbf{2 1 5}$} & Percent (\%) \\
\hline \multirow{4}{*}{ Gender } & Male & 50 & 23.3 \\
\cline { 2 - 4 } & Female & 165 & 76.7 \\
\hline \multirow{4}{*}{ Age } & 17 years and below & 3 & 1.4 \\
\cline { 2 - 4 } & $18-24$ & 161 & 74.9 \\
\cline { 2 - 4 } & $25-39$ & 50 & 23.3 \\
\hline \multirow{4}{*}{ Knowledge about cloud computing } & Intermediate & 131 & 60.9 \\
\cline { 2 - 4 } & Novice & 47 & 21.4 \\
\cline { 2 - 4 } & Savvy & 37 & 17.7 \\
\hline \multirow{5}{*}{ Frequency of using Google Drive } & Yes & 114 & 46.5 \\
\cline { 2 - 4 } & No & 101 & 53.5 \\
\hline & More than once a day & 44 & 20.5 \\
\cline { 2 - 4 } & $1-7$ times/week & 70 & 32.6 \\
\cline { 2 - 4 } & $1-3$ times/month & 52 & 24.2 \\
\cline { 2 - 4 } & Less than a month & 35 & 16.3 \\
\hline & Rarely & 14 & 6.5 \\
\hline
\end{tabular}


Table 2. Cronbach's Alpha

\begin{tabular}{|l|l|l|}
\hline \multicolumn{1}{|c|}{ Measure } & \multicolumn{1}{c|}{ No. of items } & \multicolumn{1}{c|}{ Cronbach's Alpha ( $\alpha)$} \\
\hline Perceived Usefulness (PU) & 4 & 0.846 \\
\hline Perceived Ease of Use (PEU) & 4 & 0.838 \\
\hline Perceived Speed of Access (PSA) & 4 & 0.765 \\
\hline Perceived Security (PS) & 4 & 0.870 \\
\hline Attitude Towards using Google Drive & 4 & 0.906 \\
\hline Behavioral Intention to use Google Drive & 3 & 0.906 \\
\hline
\end{tabular}

Table 3. Construct's mean, standard deviation and Pearson's correlations matrix

\begin{tabular}{|c|c|c|c|c|c|c|c|c|}
\hline & & & & & elation Matr & & & \\
\hline Mean & & SD & Perc & Perceived & Perceived & Perceived & $\begin{array}{l}\text { Attitude } \\
\text { Towards }\end{array}$ & Behavioral \\
\hline Perceived Usefulness & 3.969 & 0.695 & 1 & & & & & \\
\hline Perceived Ease of Use & 3.948 & 0.718 & $0.685^{* *}$ & 1 & & & & \\
\hline Perceive Speed of Access & 3.411 & 0.726 & $0.510 * *$ & $0.506 * *$ & 1 & & & \\
\hline Perceived Security & 3.509 & 0.768 & $0.378^{* *}$ & $0.370 * *$ & $0.379 * *$ & 1 & & \\
\hline $\begin{array}{l}\text { Attitude Towards Using } \\
\text { Google Drive }\end{array}$ & 3.737 & 0.828 & $0.731 * *$ & $0.547 * *$ & $0.482 * *$ & $0.379 * *$ & 1 & \\
\hline Behavioral Intention & 3.702 & 0.966 & $0.649^{* *}$ & $0.389 * *$ & $0.409^{* *}$ & $0.410^{* *}$ & $0.783 * *$ & 1 \\
\hline
\end{tabular}

Note: $\mathrm{n}=215$; one-tailed tests of significance were used

${ }^{*}$ Correlation is significant at the 0.01 level (1-tailed).

Pearson's correlations test is used. Consequently, the result of the correlation analysis showed that all of the proposed hypothetical relationships between the respective variables in this study were found to have a positive significant correlation with one another. There are significant positive correlations between the variable Perceived Usefulness (PU), $r=0.731, \mathrm{p}<0.01$ and Attitude towards using Google Drive as well as between Perceived Ease of Use (PEU) and Attitude towards using Google Drive, $r=$ $0.547, \mathrm{p}<0.01$. Whereas, there are moderate positive correlations between Perceived Speed of Access (PSA), $\mathrm{r}=0.482, \mathrm{p}<0.01$ and Attitude towards using Google Drive as well as between Perceived Security (PS) and Attitude towards using Google Drive, $r=0.379, p<0.01$. On the other hand, there are also strong positive correlations between Perceived Ease of Use (PEU) and Perceived Usefulness (PU), $r=0.685, p<0.01$ as well as between Attitude towards using Google Drive (A) and Behavioral Intention to use Google Drive (BI), $\mathrm{r}=0.783, \mathrm{p}<0.01$.

\subsection{Regression Analysis}

In support to the correlation analysis, a multiple linear regression analysis was also conducted to investigate further the proposed hypothetical relationship of the variables, Perceived Usefulness (PU), Perceived Ease of Use (PEU), Perceived Speed of Access (PSA) and Perceived Security (PS) with Attitude towards using Google Drive. According to Table 6, the p-value was found to be significant $(\mathrm{p}=0.000<0.05)$. Thus, the construct of Attitude towards using Google Drive was predicted by Perceived Usefulness (PU), Perceived Ease of Use (PEU), Perceived Speed of Access (PSA) and Perceived Security (PS) and these variables together explained 55.8\% of the variance in 
Table 4. The Anova table from the result of the multiple regression analysis

\begin{tabular}{|l|l|l|l|l|l|}
\hline \multicolumn{1}{|c|}{ Model } & \multicolumn{1}{c|}{ Sum of Squares } & \multicolumn{1}{c|}{ df } & \multicolumn{1}{c|}{ Mean Square } & \multicolumn{1}{c|}{ F } & \multicolumn{1}{c|}{ Sig.(p-value) } \\
\hline Regression & 81.904 & 4 & 20.476 & 66.283 & 0.000 \\
\hline Residual & 64.873 & 210 & 0.309 & & \\
\hline Total & 146.777 & 214 & & & \\
\hline
\end{tabular}

Attitude towards using Google Drive $\left(\mathrm{F}(4,210), \mathrm{p}<0.05, \mathrm{R}^{2}=0.558,95 \% \mathrm{CI}[\mathrm{a}, \mathrm{b}]\right)$ which indicates a moderately high R-squared value. According to Tables 6 and 7, the equation of the regression based on the regression analysis for the construct of Attitude towards using Google Drive is as follows:

Yi (Attitude towards using Google Drive $)=0.733(\mathrm{PU})+0.038(\mathrm{PEU})+0.134(\mathrm{PSA})$ $+0.098(\mathrm{PS})-0.120$

Thus, this reveals that the factors (PU, PEU, PSA and PS) used in the framework is moderately strong to predict Attitude towards using Google Drive. Nevertheless, it was indicated that Perceived Usefulness (PU) has the most significant effect on Attitude towards using Google Drive $(\beta=0.614, \mathrm{p}<0.05)$ (refer to Table 5$)$. Correspondingly, this shows that a unit change in the variable Perceived Usefulness (PU) has a positive impact by $61.4 \%$ to Attitude towards using Google Drive (refer to Table 5).

Table 5. The Coefficients of each variable from the multiple linear regression analysis

\begin{tabular}{|c|c|c|c|c|c|c|c|}
\hline & \multicolumn{2}{|c|}{$\begin{array}{l}\text { Understandardized } \\
\text { Estimates }\end{array}$} & \multicolumn{3}{|c|}{ Standardized Coefficients } & \multicolumn{2}{|c|}{ Collinearity Statistics } \\
\hline & B & SE & $\boldsymbol{\beta}$ & $\mathbf{t}$ & $p$-level & Tol & VIF \\
\hline Constant & -0.120 & 0.254 & & -0.471 & 0.638 & & \\
\hline $\begin{array}{l}\text { Perceived } \\
\text { Usefulness } \\
\text { (PU) }\end{array}$ & 0.733 & 0.078 & 0.614 & 9.345 & 0.000 & 0.487 & 2.054 \\
\hline $\begin{array}{l}\text { Perceived } \\
\text { Ease of Use } \\
\text { (PEU) }\end{array}$ & 0.038 & 0.075 & 0.033 & 0.500 & 0.617 & 0.491 & 2.036 \\
\hline $\begin{array}{l}\text { Perceived } \\
\text { Speed of } \\
\text { Access } \\
\text { (PSA) }\end{array}$ & 0.134 & 0.064 & 0.118 & 2.091 & 0.038 & 0.665 & 1.503 \\
\hline $\begin{array}{l}\text { Perceived } \\
\text { Security } \\
\text { (PS) }\end{array}$ & 0.098 & 0.055 & 0.091 & 1.766 & 0.079 & 0.800 & 1.250 \\
\hline R Square & 0.558 & & & & & & \\
\hline $\begin{array}{l}\text { Adjusted R } \\
\text { Square }\end{array}$ & 0.550 & & & & & & \\
\hline$* \mathrm{p}<0.05$ & & & & & & & \\
\hline
\end{tabular}

a Predictors: (Constant), perceived usefulness, perceived ease of use, perceived speed of access, perceived security $\mathrm{b}$ Dependent variable: attitude towards using google drive 
On the other hand a separate linear regression analysis was also used to further test hypothesis 3 where the result of the linear regression analysis revealed that perceived Usefulness (PU) was predicted by perceived ease of use and (PEU) explained $46.9 \%\left(\beta=0.685, p<0.05, R^{2}=0.469\right)$ of the variance in perceived usefulness (refer to Table 6). Additionally, another linear regression analysis was also used to test hypothesis 6 where it was found that Attitude towards using Google Drive was a good predictor of Behavioral intention to use Google Drive and it explained 61.3\% $(\beta=0.783, p<0.05$, $\mathrm{R}^{2}=0.613$ ) of the variance in Behavioral intention to use Google Drive.

\subsection{Hypothesis Testing Result}

Table 7 summarizes the result of the hypotheses testing. It concludes that there are significant positive linear correlations between perceived usefulness (PU) and Attitude towards using Google

Table 6. Result of multiple regression analysis

\begin{tabular}{|l|l|l|l|}
\hline Hypothetical relationship & \multicolumn{1}{|c|}{$\boldsymbol{\beta}$} & \multicolumn{1}{|c|}{$\mathbf{R}^{\mathbf{2}}$} & \multicolumn{1}{|c|}{ t-value } \\
\hline $\begin{array}{l}\text { Perceived ease of use } \\
\text { (PEU)-------> Perceived } \\
\text { usefulness (PU) }\end{array}$ & 0.685 & 0.469 & 13.721 \\
\hline $\begin{array}{l}\text { Attitude-----------> } \\
\text { Behavioral intention }\end{array}$ & 0.783 & 0.613 & 18.371 \\
\hline
\end{tabular}

Note: $n=215$; one-tailed tests of significance were used.

${ }^{*}$ Correlation is significant at the 0.01 level (1-tailed).

Table 7. Result of hypothesis testing

\begin{tabular}{|l|l|l|}
\hline \multicolumn{1}{|c|}{ Hypothesis } & \multicolumn{1}{|c|}{ r } & Support \\
\hline $\begin{array}{l}\mathrm{H}_{1}: \text { Perceived usefulness (PU) will } \\
\text { positively influence attitude towards } \\
\text { using Google Drive among the } \\
\text { students }\end{array}$ & $0.731^{* *}$ & Yes \\
\hline $\begin{array}{l}\mathrm{H}_{2}: \text { Perceived ease of use (PEU) will } \\
\text { positively influence attitude towards } \\
\text { using Google Drive among the } \\
\text { students. }\end{array}$ & $0.547^{* *}$ & Yes \\
\hline $\begin{array}{l}\mathrm{H}_{3}: \text { Perceived ease of use (PEU) } \\
\text { will positively influence perceived } \\
\text { usefulness (PU) towards using Google } \\
\text { Drive among the students. }\end{array}$ & $0.685^{* *}$ & Yes \\
\hline $\begin{array}{l}\mathrm{H}_{4}: \text { Perceived speed of access (PSA) } \\
\text { will positively influence attitude } \\
\text { towards using Google Drive among } \\
\text { the students. }\end{array}$ & $0.482^{* *}$ & Yes \\
\hline $\begin{array}{l}\mathrm{H}_{5}: \text { Perceived security (PS) will } \\
\text { positively influence attitude towards } \\
\text { using Google Drive among the } \\
\text { students. }\end{array}$ & $0.379^{* *}$ & $0.783^{* *}$ \\
\hline $\begin{array}{l}\mathrm{H}_{6}: \text { Attitude will positively influence } \\
\text { the students' behavioral intention to } \\
\text { use Google Drive. }\end{array}$ & & Yes \\
\hline
\end{tabular}

Note: $\mathrm{n}=215$; one-tailed tests of significance were used

${ }^{* *}$ Correlation is significant at the 0.01 level (1-tailed). 
Drive, between perceived ease of use (PEU) and Attitude towards using Google Drive. Significant positive linear correlations are also confirmed between perceived speed of access (PSA) and Attitude towards using Google Drive as well as between perceived security (PS) and Attitude towards using Google Drive. In addition, strong positive relationships were also found between perceived ease of use (PEU) and perceived usefulness (PU) as well as between Attitude towards using Google Drive and Behavioral intention to use Google Drive. Therefore, all of the hypotheses proposed in this study were supported (as seen in Table 9).

\section{DISCUSSION}

From the data analysis, perceived usefulness has a significant correlation with the attitude towards the use of Google Drive. Students perceived Google Drive as being a useful tool in which they would highly use in their studies for online collaboration. Also, Google Drive enhances students to do their work efficiently and increase their productivity. Similarly, a study conducted by Sadik (2016) found that many students predominantly agreed that Google Drive is useful for them as it allows them to manage digital contents remotely via the Internet. The current higher education requires more inquiry-based learning which involves students doing group work to encourage collaborative knowledge sharing and synthesis (Wai, Ng, Chiu, Ho \& Lo 2018). They also found out that students need to actively participate in a lot of projects which require tools and service to satisfy the students' needs on a wide range of collaboration. Based on a study from Jeong (2015), Google Drive was used as the web-based collaborative writing platform to create interactive and real learning tasks among the students. This indicates that Google Drive has helped the students' learning experience to become more interactive.

Results showed that perceived ease of use is significantly correlated with the attitude of students towards using Google Drive. In other words, the attitude of students towards using Google Drive is affected by the ease of using it, in such a way that it can provide convenience for the students to rely on it to do work. This goes in line with a research done by Sadik (2016) where it was discovered that most students admitted that Google Drive is easy to learn and use without the need of any technical assistance as they were able to use it as part of their educational activity such as coursework submissions. In addition another research done previously on social networking systems, in which it agreed to the importance of both perceived ease of use and perceived usefulness for the adoption of technology particularly in the environment of Web 2.0 (Kwon \& Wen, 2010). Davis (1989) also stated that the behavioral intention of a user is reflected from their attitude, hence, resulting in the projection of use towards the system. Determining factors elaborated in the technology acceptance model can be considered as major contributions that influence the approval of collaborative technologies.

Based on the results, there is a significant correlation between perceived ease of use and perceived usefulness. This means that the students' perception of the ease of using Google Drive positively correlates with their perceptions of the usefulness of Google Drive. In other words, the easier and less complicated it is to use Google Drive, the more useful it is perceived by the students. In agreement to this, past studies which have used Technology Acceptance Model (TAM) to e-learning has discovered that there is a strong positive relationship between perceived ease of use (PEU) and perceived usefulness (PU) (Ngai et al., 2007; Roca, Chiu, \& José, 2006; Van Raaij \& Schepers, 2008 as cited by Cheung \& Vogel, 2013). Similarly, Van Der Heijden (2003) concluded that users who find it easy to use the portal were likely to perceive the portal to be more useful when he researched the usage of a portal website in Netherlands. Furthermore, another study by Sadik (2016), there was a significant relationship between perceived ease of use (PEU) and perceived usefulness (PU) where the students believed that Google Drive is easier to operate and thus proved to be a useful system.

Based on the results, there is a significant correlation between speed of access and the attitude towards using Google Drive which means that the students' perceptions on the speed of access of using Google Drive positively influenced their attitude towards using the Google Drive thus the 
faster the speed of access to the service over the internet influences the students to use Google Drive services. Consequently, it is also confirmed by Neicu et al., (2020) research paper which revealed that fast internet connection positively influences the speed of access to cloud storage. In addition to that, the respondents of this study focus on students of higher education institutions which were mostly made up of the younger population between 17 to 39 years old. Hence, this finding is in line with a study by Pagani (2004) where the determinant of adopting technology is the speed of use which was perceived to be important, especially in the younger generation.

According to our results, perceived security is significantly correlated with the attitude towards the use of Google Drive. This further explains that one of the factors that lead to students' usage of Google Drive is their perception of Google Drive as a secure platform. A study conducted by Arpaci, Kilicer and Bardakci (2015) also suggested that security has a positive influence on student's attitudes in using cloud services. Security is a significant predator of adoption behavior (Arpaci, Kilicer \& Bardakci, 2015). The fact that security is a crucial determinant that can impede one's attitude towards cloud computing including cloud storage as mentioned by Dillon et al (2010), suggests that student's intention to use Google Drive has a positive influence on the perceived security. The provider of most cloud service comes with their own security as well as a system to backup customer's data and protect their data (Park and Kim, 2014). Hence, from our results and past studies, security issues play a major role in the attitude towards the new context of cloud services including Google Drive.

There is a significant correlation between attitude and behavioral intention to use Google Drive among the students. This means that the attitude of students are influenced by some factors which can be the advantages and benefits of Google Drive that lead to the intention to use Google Drive. According to Ajzen and Fishbein (1980), TRA or known as The Theory of Reasoned Action claims that one's behavior is decided by his or her behavior intention to do the behavior (attitude). Hence, the behavioral intention is determined by the person's attitude and subjective norms (Ajzen \& Fishbein, 1980). According to Chen \& Chen (2009), Intention become the best predictors of behavior in which the representation of cognitive skills of an individual's readiness to conduct a particular behavior.

\section{CONCLUSION}

Google Drive is a cloud-based technology consisting of several features to allow students to do and store their work online. It also serves as a platform for students to do collaborative work. The study supplements the existing research on cloud computing adoption as aforementioned variables reveal that all of the factors investigated in the study influenced user adoption on Google Drive.

The Technology Acceptance Model (TAM) model and two additional factors were adapted in this study. In addition to that, the first factor is the perceived usefulness (PU) which showed that the students perceived Google Drive as a useful tool in increasing the productivity in their studies as well as the efficiency in completing their work. It is then followed by the second factor; perceived ease of use (PEU) which showed that the students perceived Google Drive as easy to use and operate, thus, providing convenience for them to do work. The third factor is that both perceived ease of use (PEU) and perceived usefulness (PU) were found to have a relationship which showed that the students found Google Drive easier and less complex to use and thus, the more convenient it is perceived by the students. The fourth factor is the perceived speed of access (PSA) which was found that the speed of access to Google Drive service over the internet does influence the students to opt for its service. The final factor is the perceived security (PS) which was found that the students' decision to adopt Google Drive is influenced by the ability of Google Drive service to backup customer's data and to protect their data. Thus, the findings of this study connote that the students' perceptions on Google Drive have a significant influence towards their attitude to use Google Drive which in turn influence their behavioral intention to use Google Drive in the future. 


\section{LIMITATIONS AND SUGGESTIONS FOR FURTHER STUDY}

The limitation of this research paper is that most of the respondents were from Universiti Brunei Darussalam (UBD) compared to other targeted higher institutions in Brunei, hence, the findings does not represent the entire student population of higher education institutions in the country. A larger sample of other higher education institutions might provide a more reliable and different result on the usage of Google Drive. Nonetheless, further improvement in terms of the generalization of the findings should be considered where future researchers may attempt to expand the demographics as well as improve the number of respondents at various higher education institutions.

In addition, as a recommendation, the future scope of research should look into the students' actual usage of Google Drive during the Coronavirus disease (COVID-19) pandemic and how Google Drive has helped students during the lockdown and when social distancing are put in place to limit or reduce the spread of Coronavirus disease (COVID-19) pandemic (Coronavirus disease (COVID-19) - World Health Organization, 2020). Education institutions have greatly been affected by the Coronavirus disease (COVID-19) pandemic where all of the classes are cancelled, and students have to meet their lecturers/teachers online instead of going to college/university (Hall, 2020). With this, both educators and students have to adapt to the new norm. Hence, it is worth noting that there might be a significant increase in usage of cloud-based storage such as Google Drive among the students in higher education institutions. 


\section{REFERENCES}

Abubakar, M. (2019). Assessment of College Students' Preference on the Usage of Google Drive as a Learning Platform: An Empirical Evidence. American International Journal of Social Science Research, 4(2), 24-34. doi:10.46281/aijssr.v4i2.331

Ajzen, I. (1991). The theory of planned behavior. Organizational Behavior and Human Decision Processes, 50(2), 179-211. doi:10.1016/0749-5978(91)90020-T

Ajzen, I., \& Fishbein, M. (1980). Understanding attitudes and predicting social behavior. Prentice-Hall.

Al-Gahtani, S., \& King, M. (1999). Attitudes, satisfaction and usage: Factors contributing to each in the acceptance of information technology. Behavior \& Information Technology, 18(4), 277-297. doi: 10.1080/014492999119020

Arpaci, I., Kilicer, K., \& Bardakci, S. (2015). Effects of security and privacy concerns on educational use of cloud services. Computers in Human Behavior, 45, 93-98. doi:10.1016/j.chb.2014.11.075

Ashtari, S., \& Eydgahi, A. (2017). Student perceptions of cloud applications effectiveness in higher education. Journal of Computational Science, 23, 173-180. doi:10.1016/j.jocs.2016.12.007

Ayeh, J., Au, N., \& Law, R. (2013). Predicting the intention to use consumer-generated media for travel planning. Tourism Management, 35, 132-143. doi:10.1016/j.tourman.2012.06.010

Barbee, B., \& Prindle, D. (2018). Tips, tricks, and best practices for using Google Drive. Retrieved September 19, 2018, from https://www.digitaltrends.com/computing/how-to-use-google-drive/

Böhm, M., Leimeister, S., Riedl, C., \& Krcmar, H. (2011). Cloud computing and computing evolution. In An approach to graphs of linear forms (Unpublished work style). Unpublished.

Chandra, Y. U., \& Hartono, S. (2018, October). Analysis Factors of Technology Acceptance of Cloud Storage: A Case of Higher Education Students Use Google Drive. In 2018 International Conference on Information Technology Systems and Innovation (ICITSI) (pp. 188-192). IEEE. doi:10.1109/ICITSI.2018.8696095

Changchit, C. (2008). Data Protection and Privacy Issue. Journal Of Information Privacy And Security, 4(3), 1-2. doi:10.1080/2333696X.2008.10855842

Changchit, C., \& Chuchuen, C. (2016). Cloud Computing: An Examination of Factors Impacting Users' Adoption. Journal of Computer Information Systems, 58(1), 1-9. doi:10.1080/08874417.2016.1180651

Chen, H., \& Chen, S. (2009). The empirical study of automotive telematics acceptance in Taiwan. Int. J. Mobile Communications, 7(1), 50-65. doi:10.1504/IJMC.2009.021672

Cheung, R., \& Vogel, D. (2013). Predicting user acceptance of collaborative technologies: An extension of the technology acceptance model for e-learning. Computers \& Education, 63, 160-175. doi:10.1016/j. compedu.2012.12.003

Davis, F. (1989). Perceived usefulness, perceived ease of use, and user acceptance of information technology. Management Information Systems Quarterly, 13(3), 319-340. doi:10.2307/249008

DeLone, W., \& McLean, E. (1992). Information Systems Success: The Quest for the Dependent Variable. Information Systems Research, 3(1), 60-95. doi:10.1287/isre.3.1.60

Dillon, T., Wu, C., \& Chang, E. (2010). Cloud computing: Issues and challenges. In 24th IEEE international conference on advanced information networking and applications. IEEE.

Ercan, T. (2010). Effective use of cloud computing in educational institutions. Procedia: Social and Behavioral Sciences, 2(2), 938-942. doi:10.1016/j.sbspro.2010.03.130

Etezadi-Amoli, J., \& Farhoomand, A. (1996). A structural model of end user computing satisfaction and user performance. Information \& Management, 30(2), 65-73. doi:10.1016/0378-7206(95)00052-6

Evans, J. R., \& Mathur, A. (2005). The value of online surveys. Internet Research, 15(2), $195-219$. doi: $10.1108 / 10662240510590360$ 
Fishbein, M., \& Ajzen, I. (1975). Belief, attitude, intention and behavior: An introduction to theory and research. Academic Press.

Flavián, C., \& Guinalíu, M. (2006). Consumer trust, perceived security and privacy policy. Industrial Management \& Data Systems, 106(5), 601-620. doi:10.1108/02635570610666403

Google. (n.d.a). How we started and where we are today I Google. Retrieved September 22, 2018, from: https:// www.google.com/about/our-story/

Google. (n.d.b). Google Drive - Cloud Storage \& File Backup for Photos, Docs \& More. Retrieved September 22, 2018, from: https://www.google.com/drive/

Greenstein, S. (2000). Commercialization of the Internet: The Interaction of Public Policy and Private Choices or Why Introducing the Market Worked so Well. Innovation Policy and the Economy, 1, 151-186. doi:10.1086/ ipe.1.25056144

Hall, S. (2020). A Global View Of The Pandemic's Effect On Higher Education. Retrieved December 15, 2020 from: https://tcf.org/content/commentary/global-view-pandemics-effect-higher-education/?agreed=1

Hinton, P., McMurray, I., Brownlow, C., \& Cozens, B. (2004). SPSS explained. Routledge Taylor \& Francis Group. doi:10.4324/9780203642597

Igbaria, M. (1990). End-user computing effectiveness: A structural equation model. Omega, 18(6), 637-652. doi:10.1016/0305-0483(90)90055-E

Igbaria, M., \& Chakrabarti, A. (1990). Computer anxiety and attitudes towards microcomputer use. behavior \& Information Technology, 9(3), 229-241. doi: 10.1080/01449299008924239

Jeong, K. O. (2015). A Study on the Integration of Google Docs as a Web-based Collaborative Learning Platform in EFL Writing Instruction. Indian Journal of Science and Technology, 9(39). Advance online publication. doi:10.17485/ijst/2016/v9i39/103239

Kaiser, H. F. (1974). An index of factorial simplicity. Psychometrika, 39(1), 31-36. doi:10.1007/BF02291575

Khansa, L., \& Zobel, C. (2014). Assessing Innovations in Cloud Security. Journal of Computer Information Systems, 54(3), 45-56. doi:10.1080/08874417.2014.11645703

Kovach, S. (2012). What's So Special About Google Drive? Retrieved September 19, 2018, from https://www. businessinsider.com/what-is-google-drive-2012-4

Kwon, O., \& Wen, Y. (2010). An empirical study of the factors affecting social networking service use. Computers in Human Behavior, 26(2), 254-263. doi:10.1016/j.chb.2009.04.011

Lederer, A., Maupin, D., Sena, M., \& Zhuang, Y. (2000). The technology acceptance model and the World Wide Web. Decision Support Systems, 29(3), 269-282. doi:10.1016/S0167-9236(00)00076-2

Lee, D. (1986). Usage Pattern and Sources of Assistance for Personal Computer Users. Management Information Systems Quarterly, 10(4), 313. doi:10.2307/249183

Lee, Y., Kozar, K., \& Larsen, K. (2003). The technology acceptance model: Past, present and future. Communications of the Association for Information Systems, 12(1), 752-780. doi:10.17705/1CAIS.01250

Mary, T., \& Rose, P. (2020). The Impact of Graduate Student's Perceptions towards Usage of Cloud Computing in Higher Education Sectors. Universal Journal of Educational Research, 8(11), 5463-5478. doi:10.13189/ ujer.2020.081150

McGuire, W. J. (1969). The Nature of Attitudes and Attitude change. In G. Lindzey \& E. Aronson (Eds.), The Handbook of Social Psychology (2nd ed., Vol. 3). Addison-Wesley.

Neicu, A., Radu, A., Zaman, G., Stoica, I., \& Răpan, F. (2020). Cloud Computing Usage in SMEs. An Empirical Study Based on SMEs Employees Perceptions. Sustainability, 12(12), 4960. doi:10.3390/su12124960

Ngai, E., Poon, J., \& Chan, Y. (2007). Empirical examination of the adoption of WebCT using TAM. Computers \& Education, 48(2), 250-267. doi:10.1016/j.compedu.2004.11.007 
Olanrewaju, R., Islam Khan, B., Islam Mattoo, M., Anwar, F., Bt. Nordin, A., Naaz Mir, R., \& Noor, Z. (2017). Adoption of Cloud Computing in Higher Learning Institutions: A Systematic Review. Indian Journal of Science and Technology, 10(36), 1-19. doi:10.17485/ijst/2017/v10i36/117641

Pagani, M. (2004). Determinants of adoption of third generation mobile multimedia services. Journal of Interactive Marketing, 18(3), 46-59. doi:10.1002/dir.20011

Page, L., \& Pichai, S. (2015). Alphabet Investor Relations. Alphabet Investor Relations. Retrieved September 24, 2018, from https://abc.xyz/investor/founders-letters/2015/

Park, E., \& Kim, K. (2014). An Integrated Adoption Model of Mobile Cloud Services: Exploration of Key Determinants and Extension of Technology Acceptance Model. Telematics and Informatics, 31(3), 376-385. doi:10.1016/j.tele.2013.11.008

Robey, D. (1979). User Attitudes and Management Information System Use. Academy of Management Journal, 22(3), 527-538. doi:10.5465/255742

Roca, J. C., Chiu, C. M., \& José, F. (2006). Understanding e-learning continuance intention: An extension of the technology acceptance model. International Journal of Human-Computer Studies, 64(8), 683-696. doi:10.1016/j. ijhcs.2006.01.003

Rouse, M. (2012). What is Google Drive? - Definition from WhatIs.com. Retrieved September 19, 2018, from https://searchmobilecomputing.techtarget.com/definition/Google-Drive

Sadik, A. (2016). Students' acceptance of file sharing systems as a tool for sharing course materials: The case of Google Drive. Education and Information Technologies, 22(5), 2455-2470. doi:10.1007/s10639-016-9556-z

Sclater, N. (2009). Cloudworks, eLearning in the Cloud. http://cloudworks.ac.uk/cloud/view/2430/

Shana, Z., \& Abulibdeh, E. (2017). Cloud Computing Issues for Higher Education: Theory of Acceptance Model. International Journal of Emerging Technologies in Learning, 12(11), 168. doi:10.3991/ijet.v12i11.7473

Swanson, E. (1982). Measuring user attitudes in MIS research: A review. Omega, 10(2), $157-165$. doi:10.1016/0305-0483(82)90050-0

Szajna, B. (1996). Empirical Evaluation of the Revised Technology Acceptance Model. Management Science, 42(1), 85-92. doi:10.1287/mnsc.42.1.85

TechNavio. (2016). Global Cloud Computing Market in Higher Education 2016-2020. TechNavio. Retrieved from https://www.technavio.com/report/global-education-technology-global-cloud-computing-market-highereducation-2016-2020

Thompson, R., Compeau, D., \& Higgins, C. (2006). Intentions to use information technologies: An integrative model. Journal of Organizational and End User Computing, 18(3), 25-46. doi:10.4018/joeuc.2006070102

Thompson, R., Higgins, C., \& Howell, J. (1991). Personal Computing: Toward a Conceptual Model of Utilization. Management Information Systems Quarterly, 15(1), 125. doi:10.2307/249443

Torkzadeh, G., \& Dwyer, D. (1994). A path analytic study of determinants of information system usage. Omega, 22(4), 339-348. doi:10.1016/0305-0483(94)90060-4

Van der Heijden, H. (2003). Factors influencing the usage of websites: The case of a generic portal in The Netherlands. Information \& Management, 40(6), 541-549. doi:10.1016/S0378-7206(02)00079-4

Van Raaij, E. M., \& Schepers, J. J. L. (2008). The acceptance and use of a virtual learning environment in China. Computers \& Education, 50(3), 838-852. doi:10.1016/j.compedu.2006.09.001

Venkatesh, V., \& Davis, F. (2000). A theoretical extension of the technology acceptance model: Four longitudinal field studies. Management Science, 46(2), 186-204. doi:10.1287/mnsc.46.2.186.11926

Venkatesh, V., Morris, M. G., Davis, G. B., \& Davis, F. D. (2003). User acceptance of information technology: Toward a unified view. Management Information Systems Quarterly, 27(3), 425-478. doi:10.2307/30036540

Vise, D. (2007). The Google Story. Strategic Direction, 23(10). Advance online publication. doi:10.1108/ sd.2007.05623jae.001 
Wai, I. S. H., Ng, S. S. Y., Chiu, D. K., Ho, K. K., \& Lo, P. (2018). Exploring undergraduate students' usage pattern of mobile apps for education. Journal of Librarianship and Information Science, 50(1), 34-47. doi:10.1177/0961000616662699

Wang, W. H., \& Liu, Y. J. (2009). Attitude, behavioral intention and usage: An empirical study of Taiwan Railway's internet ticketing system. Taiwan: National Taiwan Ocean University.

Warshaw, P., \& Davis, F. (1985). Disentangling behavioral intention and behavioral expectation. Journal of Experimental Social Psychology, 21(3), 213-228. doi:10.1016/0022-1031(85)90017-4

Who.int. (2020). Coronavirus Disease (COVID-19) - World Health Organization. Retrieved December 15, 2020 from https://www.who.int/emergencies/diseases/novel-coronavirus-2019 


\section{APPENDIX}

SAMPLE SURVEY ITEMS

A. DEMOGRAPHICS

\begin{tabular}{ll}
\hline Items & \\
\hline Gender & Male \\
& Female \\
\hline Age group & 17 years old and below \\
& $18-24$ years old \\
& $25-39$ years old \\
& $40-60$ years old \\
& 60 plus years old \\
\hline Level of Studies & Diploma \\
& Unibridge \\
& Undergraduate \\
& Postgraduate \\
\hline
\end{tabular}

B. IT LITERACY \& CLOUD COMPUTING

\begin{tabular}{|c|c|}
\hline \multicolumn{2}{|l|}{ Items } \\
\hline $\begin{array}{l}\text { General IT skills } \\
\text { (self-perception) }\end{array}$ & $\begin{array}{l}\text { Novice } \\
\text { Intermediate } \\
\text { Savvy }\end{array}$ \\
\hline $\begin{array}{l}\text { How would you rate yourself with } \\
\text { respect to your knowledge about } \\
\text { how computer storage works? }\end{array}$ & 1 (very poor) 234567 (excellent) \\
\hline $\begin{array}{l}\text { Prior to this survey, have you heard } \\
\text { of cloud computing? }\end{array}$ & $\begin{array}{l}\text { Yes } \\
\text { No }\end{array}$ \\
\hline $\begin{array}{l}\text { If Yes, do you use Google } \\
\text { Drive? }\end{array}$ & $\begin{array}{l}\text { Yes } \\
\text { No }\end{array}$ \\
\hline $\begin{array}{l}\text { If Yes, how often do you } \\
\text { use Google Drive? }\end{array}$ & $\begin{array}{l}\text { more than once a day } \\
1-7 \text { times/week } \\
1-3 \text { times /month } \\
\text { less than once a month }\end{array}$ \\
\hline $\begin{array}{l}\text { If Yes, do you use Google } \\
\text { Drive? }\end{array}$ & $\begin{array}{l}\text { Yes } \\
\text { No }\end{array}$ \\
\hline $\begin{array}{l}\text { If Yes, how often do you } \\
\text { use Google Drive? }\end{array}$ & $\begin{array}{l}\text { more than once a day } \\
1-7 \text { times/week } \\
1-3 \text { times month } \\
\text { less than once a month }\end{array}$ \\
\hline $\begin{array}{l}\text { Used Google Drive } \\
\text { for }\end{array}$ & $\begin{array}{l}\text { Storage service (backup files) } \\
\text { Collaborative tools (Google Docs, Google Sheets, Google Slides, } \\
\text { Google Forms) } \\
\text { Online workspace }\end{array}$ \\
\hline $\begin{array}{l}\text { Do you use Google Drive to } \\
\text { backup files online? }\end{array}$ & $\begin{array}{l}\text { Yes } \\
\text { No }\end{array}$ \\
\hline $\begin{array}{l}\text { If Yes, how often do you } \\
\text { use Google Drive service to } \\
\text { store files? }\end{array}$ & $\begin{array}{l}\text { more than once a day } \\
1-7 \text { times week } \\
1-3 \text { times month } \\
\text { less than once a month }\end{array}$ \\
\hline \multicolumn{2}{|c|}{$\begin{array}{l}\text { C. INDIVIDUAL PERCEPTION AND USAGE OF GOOGLE DRIVE } \\
5 \text { points Likert scale questions were used to measure the variables as follows: }\end{array}$} \\
\hline \multicolumn{2}{|l|}{ Items } \\
\hline \multirow[t]{4}{*}{ Perceived Usefulness (PU) } & $\begin{array}{l}\text { Google Drive enables me to do my work/assignments quickly and } \\
\text { increase my productivity }\end{array}$ \\
\hline & $\begin{array}{l}\text { Google Drive increase the convenience of doing my } \\
\text { work/assignment especially collaborative work }\end{array}$ \\
\hline & Using Google Drive enhance the efficiency of my work/assignment \\
\hline & The advantages of Google Drive outweigh its disadvantages \\
\hline \multicolumn{2}{|c|}{ 1-Strongly disagree 2 -- Disagree 3 - Neutral 4-Agree 5 -- Strongly agree } \\
\hline \multirow[t]{4}{*}{ Perceived Ease of Use (PEU) } & I believe it is easy to understand how Google Drive works \\
\hline & Learning to operate Google Drive is easy for me \\
\hline & I find it easy to use Google Drive to do my work \\
\hline & Using Google Drive does not require me to have good skills in $\mathrm{IT}$ \\
\hline 1 -- Strongly disagree 2 . & -Disagree 3 -- Neutral 4 - Agree 5 -- Strongly agree \\
\hline
\end{tabular}




\begin{tabular}{|c|c|}
\hline \multirow{5}{*}{ Perceived Speed of Access (PSA) } & $\begin{array}{l}\text { I believe that the speed of Google Drive is the same as working on } \\
\text { files stored on a traditional laptop or PC. }\end{array}$ \\
\hline & $\begin{array}{l}\text { I believe that the speed of Google Drive is sufficient for backup and } \\
\text { storage. }\end{array}$ \\
\hline & \\
\hline & $\begin{array}{l}\text { I believe that the speed of Google Drive to upload/download files is } \\
\text { the same as uploading/downloading to any other Internet website. }\end{array}$ \\
\hline & $\begin{array}{l}\text { I believe that the speed of Google Drive is sufficient for my } \\
\text { everyday work. }\end{array}$ \\
\hline \multicolumn{2}{|c|}{ 1-- Strongly disagree 2 -- Disagree 3 -- Neutral 4 --- Agree 5 -- Strongly agree } \\
\hline \multirow[t]{4}{*}{ Perceived Security (PS) } & $\begin{array}{l}\text { I believe that by using Google Drive, the company (Google) that } \\
\text { provides the service will protect my data from the theft. }\end{array}$ \\
\hline & $\begin{array}{l}\text { I believe that by using Google Drive, the company (Google) that } \\
\text { provides the service will prevent unauthorized access to my files. }\end{array}$ \\
\hline & $\begin{array}{l}\text { I believe that by using Google Drive, the company (Google) that } \\
\text { provides the service will have the means to prevent the loss of my } \\
\text { data. }\end{array}$ \\
\hline & $\begin{array}{l}\text { I believe that by using Google Drive, the company (Google) that } \\
\text { provides the service will encrypt my data. }\end{array}$ \\
\hline \multicolumn{2}{|c|}{ 1-- Strongly disagree 2 -- Disagree 3 -- Neutral 4 -- Agree 5 --- Strongly agree } \\
\hline \multirow{4}{*}{$\begin{array}{l}\text { Attitude Towards Using Google } \\
\text { Drive }\end{array}$} & I like using Google Drive to do my work/assignment \\
\hline & Using Google Drive to do work/assignment is a good idea \\
\hline & I find using Google Drive to be enjoyable \\
\hline & I have fun using Google Drive \\
\hline \multicolumn{2}{|c|}{ 1-- Strongly disagree 2 --- Disagree 3 -- Neutral 4 -- Agree 5 --- Strongly agree } \\
\hline \multirow{3}{*}{$\begin{array}{l}\text { Behavior Intention to use Google } \\
\text { Drive }\end{array}$} & $\begin{array}{l}\text { I would intend to use Google Drive in my daily tasks (e.g. } \\
\text { Assignments or Uni related work) as often as needed }\end{array}$ \\
\hline & $\begin{array}{l}\text { Whenever possible, I would intend to use Google Drive in my daily } \\
\text { tasks (e.g. assignments or Uni related work) }\end{array}$ \\
\hline & $\begin{array}{l}\text { I would estimate that my chances of using Google Drive in my daily } \\
\text { tasks (e.g. Assignments or Uni related work) are frequent. }\end{array}$ \\
\hline \multicolumn{2}{|c|}{ 1-- Very unlikely 2 -- Unlikely 3 -- Neutral 4 -- Likely 5 -- Very Likely } \\
\hline
\end{tabular}

Mohammad Nabil Almunawar is currently an associate professor at the School of Business and Economics, Universiti of Brunei Darussalam (UBDSBE), Brunei Darussalam. He received his bachelor's degree in 1983 from Bogor Agricultural University, Indonesia, master's degree (MSc) from the Department of Computer Science, University of Western Ontario, London, Canada in 1991, and Ph.D. from the University of New South Wales in 1998. Dr. Almunawar has published more than 100 papers in refereed journals, books, book chapters, and international conference proceedings. He has more than 30 years of teaching experience in the area of information systems. His overall research interests include applications of IT in management, e-business/commerce, digital marketplace/ platform, digital business ecosystem, health informatics, information security, and cloud computing. Currently, he focuses his research on digital platform and digital business ecosystem. 